Halidahon Bakhtiyarova, Dr. of education sciences, Prof. National Transport University, Kyiv, Ukraine Natalia Postoiuk, Ph.D. (Pedagogical of Sci.), Assist. Prof. Taras Shevchenko National University of Kyiv, Kyiv, Ukraine

\title{
WAYS OF FORMATION OF VALUES AND VALUE PROFESSIONAL ORIENTATIONS OF STUDENTS OF HIGHER EDUCATION INSTITUTIONS OF UKRAINE
}

\begin{abstract}
Aspects of formation of values and value professional orientations of student youth in higher institutions of Ukraine have been revealed. Approaches to the interpretation of the essence of "values", "professional values", "moral values", "value professional orientations" in the scientific program have been described; the current state of formation of professional values of student youth in professional training of higher educational institution has been researched; the pedagogical conditions of formation of professional values of future specialists in professional training have been theoretically substantiated.

Keywords: value, professional value, personal qualities, professional training, formation of professional values, pedagogical conditions.
\end{abstract}

Introduction. This problem becomes especially actual in modern conditions, because the new model of higher education should be based on values, professional values, principles of democracy and humanism and contribute to the creation of conditions for personal development, selfrealization of student youth. Teachers have a leading role in shaping future creators of new life in Ukraine, because they have to educate national consciousness, political culture, spiritual and ethical qualities and culture of individual behavior, patriotism and culture of interethnic relations, planetary consciousness. However, the teachers themselves must be worthy citizens of their country with clearly defined moral values and priorities. Therefore, there is a problem of formation in future specialists of higher educational institutions of value orientations, social position, which is based on values and professional values. The formed social position of modern student youth is determined by social maturity, it affects the level of civic consciousness, ensures the assimilation of basic values and moral norms of a democratic society, mastering the tools for analysis and making optimal decisions in specific life and professional situations [Kalashnikova L., 2014].

The purpose of the research: to theoretically substantiate the essence of values and professional values of youth, pedagogical conditions of formation of professional values of student youth in professional training of higher education institution of Ukraine.

The object of research is the process of formation of professional values of student youth in professional training of higher education institution of Ukraine.

The subject of research - pedagogical conditions for the formation of professional values of future professionals who study in the specialty "015 Professional Education (Transport)".

The purpose, object, subject of research caused of the following tasks: 1) to reveal the degree of elaboration of the problem of formation of professional values of future specialists in higher education institution on the basis of the analysis of scientific and pedagogical literature; 2) to clarify the essence of the concepts of "values" and "professional values"; to determine the features of professional values of future specialists in higher education institution in the scientific literature; 3 ) to research the current state of formation of professional values of future specialists in higher education institution in professional training; 4) to theoretically substantiate the pedagogical conditions for the formation of professional values of future specialists in higher education institution in professional training.

The research hypothesis is that the formation of professional values of future teachers in higher education will be effective if the educational process of higher education the following pedagogical conditions will be implemented: 1) the formation of positive motivation of future professionals to the profession and the need for ethical regulation of their own professional actions; 2) updating of educational and methodical support and essential-content saturation of professional training of future specialists in higher education institution (due to the development and implementation of a special course and enrichment of the content of professional disciplines with axiological component); 3) ensuring system and complexity in selfassessment of professional activity, self-knowledge regarding the acquisition of groups of professional values, namely: humanistic, deontological, communicative, competence, emotional-volitional, organizational.

Analysis of recent research and publications. The modern scientific and pedagogical literature presents a significant block of works on the theory and practice of solving the problem of training future professionals (I. Bekh, S. Goncharenko, M. Yevtukh, I. Zyazyun, B. Korotyaev, S. Konoshenko, K. Kostyuk, O. Leontiev, V. Steshenko, G. Trotsko and others). The theoretical basis of the study were scientific works, which revealed: the essence and content of values in the structure of personality in the days of ancient philosophers (Aristotle, Democritus, Heraclitus, Plato, Plutarch, Socrates); social, psychological and pedagogical axiological concepts (G. Asmolov, T. Butkivska, M. Kagan, M. Scheler, N. Shust, D. Uznadze, etc.); definitive analysis of the concepts "values", "professional values" in the context of professional training (N. Belyaev, O. Bezpalko, F. Gonobolin, B. Olshansky, A. Petrovsky, V. Shpalinsky, V. Tugarinov, G. Zhyrska, T. Lyubimov, V. Vodzynska, V. Yadov).

The problem of formation of value orientations in higher education is covered in the works of O. Adamenko, G. Vasyanovych, V. Verbets, S. Honcharenko, S. Krymsky, V. Slastyonin, O. Sukhomlynska and others.

The basic concepts of the theory of values are reflected in the domestic philosophical literature (studies of V. Andrushchenko, V. Kremen, V. Molodychenko, B. Chizhevsky, etc.) and the works of foreign scientists (A. Maslow, K. Rogers, V. Frankl, etc.). These scientists have determined the categorical apparatus of the theory of values, developed the main methodological provisions, according to which values are considered as the relationship of objective and subjective, relative and absolute, ie the natural nature of values and attitudes to them.

Presentation of the main positions. The problem of formation of professional values of higher education institution students in pedagogical science is currently at the stage of comprehension and development, which is due to radical changes in the structure of the labor market, diversification of forms of professional employment and therefore focused public attention to the formation of future teachers' "professional values". 
Addressing the interdisciplinary context of the study testified to the multifaceted conceptual range, the need to analyze such concepts as "values", "professional values", "moral values", "values of socio-pedagogical activities". Modern scientists, continuing the study of "values", "professional values" as social regulations and coordinates of social (professional) behavior of the individual, emphasized their dominant place in the personality structure of the specialist [Bekh I., 2008; Hordyeyeva K., 2014; Etyka, 2002; Kalashnikova L., 2014; Solovey, 2013; Tsinnosti..., 1997].

The term "value" was firstly used by Apistotle and it was introduced into philosophical circulation in the 60's of the XIX century by German neo-Kantians W. Windelbad and G. Rickert. Values are studied by "axiology", or the theory of values, and were introduced in the early twentieth century. Thus value is considered by many sciences, value phenomena can be considered at different levels of abstraction. Value can be interpreted as a conceptual construction that belongs to the system of different levels of abstraction of personal, social, cultural, biological; it is an integral part of man's relationship with the world in which there is life and knowledge; these are the properties of being that are created by a person or that have a certain relation to them. In the theory of values, the category of "values" acts as dependent on historical development, social conditions, social relations, the dialectic of absolute and relative, objective and subjective [Entsyklopediya osvity, 2008, p. 992].

The main definition of the concept of "value" is the significance of certain realities of reality in terms of meeting material and spiritual needs, human interests; it is something that can value a person that is meaningful and important.

One of the most common definitions of value defines it as the significance of certain realities of reality in terms of human needs and society. This category is closely related to the categories "need", "interest" (very close, but not identical concepts) [Etyka, 2002].

In pedagogical research, the problems of values have been revealed in unity with other important areas of education and upbringing: in the system of civic national, moral, aesthetic and labor education; values of family upbringing; features of the formation of values at different age periods of human life.

Researchers also consider the category of "value attitude" as a general scientific concept that has important epistemological significance for pedagogy and psychology. The inclusion of values in the structure of personality allows, according to scientists, to identify the most common social determinants of behavior, the source of which should be sought in morality, social daily life [Entsyklopediya osvity, 2008, p. 989].

A special kind of value attitude is moral attitude. The most stable value attitudes are the value orientations of the individual, which are an important element of moral consciousness, which gives spiritual certainty to the system of motives [Etyka, 2002, p. 112].

The value attitude to a person is based on the original thesis that a person is an absolute value, the highest substance, the "measure of all things". It should be seen as a special aspect of the humanization of relations, because the person who is their subject, becomes the main value and direct object of their interaction. Value attitude to a person, recognition of their highest value also contains behavioral aspects of the culture of human relations, which in everyday life have the form of various technologies "activities and behavior (V. Belousov).

Moral values, generated by the value attitude to a person, are aimed at establishing in all spheres of human life (including interpersonal relations) the principles of humanism, the elevation of human dignity, the humanization of interpersonal relationships. They constitute the semantic side of the moral culture of students and teachers [Bekh I., 2008].

It is noteworthy that researchers consider the essence of the term "value orientation" as a relatively stable system of interests and needs of the individual to a certain hierarchy of life values, the tendency to give preference to certain values in different life situations, a way to distinguish personal phenomena and objects in terms of their significance for humans. Value orientations are important elements of personality structure. This is an internal component of human consciousness and self-consciousness. Like values, they play a very active role in determining the direction of moral activity of the individual; they are a fairly stable system, its main determinants are material living conditions, level of general culture, beliefs, inclinations, abilities, human abilities, personal meanings, moral principles, the value system of the individual, society or a particular reference group. They are formed in the process of socialization, fulfillment of social roles, assimilation of the system of social values. In the structure of human activity, value orientations are closely related to the cognitive and volitional qualities of the individual. In the process of joint activity, which determines the relationships of people in groups, group value orientations are formed. The system of value orientations forms the semantic side of the orientation of the individual and reveals the inner basis of his attitude to reality. Developed value orientations of the personality are an indicator of its maturity and formation, underdevelopment of value orientations - a sign of infantilism. Value orientations significantly affect the style of thinking, lifestyle, the course of emotional processes [Entsyklopediya osvity, 2008; Etyka 2002]. The term "professional values" in accordance with various scientific areas (philosophical, historical pedagogical, socio - pedagogical), made it possible to define it as the basis of socio - pedagogical activities of the individual, which includes professional responsibility, essential - substantive saturation of pedagogical work, its moral aspect, certain principles and specific professional relations with children, colleagues, representatives of various social institutions.

Under the definition of "professional values" we understand the basis of personal acceptance as a qualified representative of a particular profession; integrative basis of activity of both an individual (representative of a certain profession) and any small or large social group (professional team); reference point for qualified performance and observance of certain responsibilities, for professional responsibility for their activities [Hordyeyeva K., 2014, p. 7].

Based on the study of historical and pedagogical literature on the problem, it is determined that the value professional orientations of a person are the most important structural component of the culture of self-determination of the future teacher and constitute a dialectical unity of sensory, rational, effective, social and individual as one of the main "global" characteristics.

Value orientations are a complex, multilevel system closely linked to the diverse hierarchy of values that underlie it. Depending on the basis of existing classifications, there are different groups of values:

a) values - objects as objects of our evaluations and values - values, which are the very criteria, standards of evaluation;

b) material, social and spiritual values cognitive, scientific, aesthetic, artistic, moral, etc.);

c) by the nature of participation in the regulation of behavior we distinguish values - goals, values - norms, values - ideals, values - means;

d) depending on the type of human activity values are divided into professional, political, leisure values, etc. 
One of the leading places in the system of value orientations of the individual belongs to orientations on professional values, the formation of which researchers consider the most important condition not only for professional self-determination, but also the formation of the young person's personality in general [Bekh I. 2008]. Modern science has proven the decisive influence of human professional activity, its social roles on the behavior and communication of the individual (G. Vasyanovich, O. Vyshnevsky, V. Volkova, V. Grinyova, O. Dubasenyuk, V. Semchenko, M. Smetansky, etc.).

Thus, professional value orientations have a decisive influence on both professional and personal selfdetermination of the teacher, they mediate all pedagogical activities. The formation of professional value orientations as the basis of motivational value attitude to the pedagogical profession, according to researchers, determines the formation of the executive (procedural) component of professional readiness, which is derived from the level of their development (G. Ball, G. Nagorna, O. Savchenko, R. Skulsky, V. Slastyonin, L. Soldatova, I. Strakhov, etc.). The presence of professionally significant value orientations in the individual provides a conscientious attitude to the case, encourages it to search, creativity, improvement and, to some extent, compensates for the underdeveloped skills and abilities; lack of positive orientation can cause professional collapse, loss of existing skills.

Pedagogical activity, like any other, is purposeful, and the target determination of human activity is a value determination. Goals can influence human activity as ideal values, the realization of which a person considers as an urgent need (I. Bekh, M. Boryshevsky, G. Kostyuk, Z. Pavlyutenkova, T. Troitskaya, N. Chavchavadze, etc.)

Thus, the study of the structural components of the education of value professional orientations of student youth in higher educational institutions of Ukraine allows to build in the minds of teachers an ideal model of their activities, which becomes a guide in professional self-determination and self-improvement. The crucial role of the influence of orientations on professional values in the system of value orientations of the teacher is confirmed by a number of researches in which the specifics of some professionally significant value orientations of future teachers are studied and possible ways and ways of their formation are outlined. Within the axiology of pedagogical education, various classifications of pedagogical values have been developed, the appropriation of which ensures the formation of the teacher's value orientations (N. Astashova, L. Blinov, I. Isayev, M. Shevchuk, E. Shiyanov, etc.).

The process of forming "professional values" of student youth should take into account the peculiarities of student age; focus on different role positions, the desire to confirm the correct choice of profession, active involvement in more active relationships, mediated by a system of social values and ideals, etc.

To ensure the successful process of formation of professional values of students of higher educational institutions it is necessary to adhere to the following pedagogical conditions [Hordyeyeva K., 2014, p. 182-188]:

1) formation of positive motivation of future specialists to the profession and the need for ethical regulation of their own professional actions, which is based on the activation of educational and cognitive activities of students (students acquire significant professional motives that ensure a harmonious process of becoming a specialist, his skills of pedagogical work, interest in various components of professional activity and desire to have a positive result of your work); diversification of forms and methods of teaching; changes in the work program of educational disciplines ("Introduction to the specialty", etc.); demonstration of social videos, the actual purpose of which corresponded to the blocks of professional values, which are formed in the process of professional training (humanistic, ethnological, deontological);

2) formation of professional values of specialists in the process of professional training, which is correlated with the implementation of such stages of the mechanism of formation of professional values of specialists as: response stage (contains substages: subordinate response, voluntary response, satisfaction with response), stage of assimilation of professional values (contains substages: acceptance of professional values, prevalence of preferences), prevalence of professional values, conviction), the stage of organization of professional values (contains substages: conceptualization of professional values, organization of the system of professional values).

3) ensuring systematic and comprehensive selfassessment of professional activity, self-knowledge on the acquisition of groups of professional values, namely: humanistic, deontological, communicative, competence, emotional-volitional, organizational. It provides for a systematic comprehensive diagnosis of the effectiveness of professional values during professional training.

Conclusions. According to the analysis of philosophical and psychological-pedagogical literature, it was found that the problem of formation of values and professional values of student youth in higher educational institutions has not acquired a comprehensive scientific study. The professionally significant qualities of the future specialist include the qualities required in the activities of specialists in this profession, affect the success of educational activities, allow the fullest realization of personal potential and the development of which provides further high quality professional activity.

The genesis of the researched problem as a social and pedagogical phenomenon has been revealed; analysis of the state of the studied aspects allowed to study this process in dynamics. It is shown that the development of professional values took place in accordance with the evolution of historical and socio-cultural values, as the unity of high spirituality and morality, which also affected the quality of training of higher education.

The essence of the concepts "values" and "professional values" in the scientific paradigm has been specified. A systematic approach to the study of the research problem allowed us to establish that in the modern scientific paradigm the definition of "value" is considered in the threedimensional plane, namely: psychological problem, pedagogical problem, social problem. It was found that, depending on the context, a number of theoretical concepts are distinguished, which determine the essentialsubstantive saturation of the concept of "value" ("functional" concept, "evaluation" concept, "significant" concept).

The interdisciplinary context of the analysis of the concepts "values" and "professional values", taking into account socio-cultural and psychological determinants of professional training of future specialists in higher education institution caused the definition of "professional values" as a complex multilevel formation, a certain coordinate system and relevant regulations of the process of professional activity of a specialist. Professional values of student youth include professional responsibility, substantive saturation of pedagogical work, its moral aspect, certain principles and specific professional relationships with students, colleagues, representatives of various social institutions. 
The peculiarities of professional values of specialists in higher education institution, which are based on the deontological paradigm of certain norms of pedagogical work, have been clarified. The main blocks of professional values of future specialists in higher education pedagogy contain groups of professional values that are formed in the process of professional training, namely: humanistic block (patience, kindness, sensitivity, altruism); deontological block (tolerance, tact, restraint, correctness, confidentiality); communicative block (contact, politeness, openness, attentiveness); competence unit (dedication, awareness, objectivity, diligence, education); emotional-volitional block (persistence, determination, activity, optimism); organizational (discipline, punctuality, concentration, neatness, composure).

The study does not cover all aspects of the problem. The perspective areas of further research include the development of didactic support for the formation of professional values of future professionals in higher education pedagogy and improving the mechanisms of formation of professional values of future teachers who have different levels of their formation.

Список використаних джерел

Бех І. Виховання особистості : навч. посібник / І. Бех-К.: Либідь, 2008. $-848 \mathrm{c}$.
Гордєєва К. Професійні цінності в системі соціально-педагогічної роботи: психологічний аспект / К. Гордєєва / Гуманізація навчально-виховного процесу: збірник наукових праць / за заг. ред. проф. В. І. Сипченка. Слов'янськ: ДДПУ, 2014. - Вип. LXVIII. - Ч. І. - С. 182-188.

Енциклопедія освіти / за ред. В.Г. Кремень. - К.: Юрінком Інтер, 2008. $1040 \mathrm{c}$.

Етика / за ред. В.О. Лозовой, М.І. Панов, О.А. Стасевська та ін. - К. Юрінком Інтер, 2002. - 224 с. - С. 103

Калашнікова Л. Умови формування соціальної позиції студента / Л. Калашнікова // Педагогіка та психологія. - 2014. - Вип. 45. - С. 125-134.

Соловей М. Професійно-педагогічна під готовка майбутнього вчителя в кредитно-модульній системі організації навчання: навчальний посібник / М. Соловей, В. Кудіна, Є. Спіцин. - К.: Ленвіт, 2013. - 414 с. - С. 148. Цінності освіти і виховання / О.В. Сухомлинська. - К., Знання, 1997. $231 \mathrm{c}$.

\section{References}

Bekh, I. (2008). Bykhovannya osobystosti: [navch. posibnyk]. K.: Lybid'. 848 s. Hordyeyeva, K. (2014). Profesiyni tsinnosti v systemi sotsial'nopedahohichnoï roboty: p'sykholohichnyy aspekt / Humanizatsiya navchal'novykhovnoho protsesu: zbirnyk naukovykh prats' / [za zah. red. prof. B. I. Sypchenka]. Slov'yans'k: DDPU. Bypusk LXVIII. CH. I. S. $182-188$. Entsyklopediya osvity (2008). Za red. B.H.Kremen'. K.: Yurinkom Inter. 1040 s.

Etyka (2002). Za red. B.O.Lozovoy, M.I.Panov, O.A.Stasevs'ka ta in. K.: Yurinkom Inter. 224 s. S. 103

Kalashnikova, L. (2014). Umovy formuvannya sotsial'noï pozytsiï studenta. / Pedahohika ta p'sykholohiya. Byp. 45. S. 125-134.

Solovey, M. Kudina, B. Spitsyn, YE. (2013). Profesiyno-pedahohichna pid hotovka maybutn'oho vchytelya $v$ kredytno-modul'niy systemi orhanizatsiï navchannya: [navchal'nyy posibnyk] K.: Lenvit. 414 s. S.148.

Tsinnosti osvity i vykhovannya (1997) / O.B.Sukhomlyns'ka. K., Znannya. 231 s. Надійшла до редколегії 15.04.21

Халідахон Бахтіярова, канд. пед. наук, проф.

Національний транспортний університет, Київ, Україна

Наталія Постоюк, канд. пед. наук, асист.

Київський національний університет імені Тараса Шевченка, Київ, Україна

\section{ШЛЯХИ ФОРМУВАННЯ ЦІННОСТЕЙ ТА ЦІННІСНИХ ПРОФЕСІЙНИХ ОРЕНТАЦІЙ СТУДЕНТІВ ЗАКЛАДІВ ВИЩОЇ ОСВІТИ УКРАЇНИ}

Розкрито аспекти формування цінностей та ціннісних професійних орієнтацій студентської молоді у закладах вищої освіти України. Розкрито підходи до трактування сутності "цінності", "професійні цінності", "моральні цінності", "ціннісне ставлення", "ціннісні професійні орієнтації" у науковій програмі; досліджено сучасний стан формування професійних цінностей студентської молоді у фаховій підготовці закладу вищої освіти; теоретично обґрунтовано педагогічні умови формування професійних цінностей майбутніх фахівців у професійній підготовці.

Ключові слова: цінність, професійна цінність, особисті якості, професійна підготовка, фахівець із педагогіки вищої школи, формування професійних цінностей, педагогічні умови. 